\title{
Skuespillerfaget som lønarbejde og kønskonstruktion
}

Af Karen Sjørup og

Charlotte KirkegaARD

Begrebet 'skuespillerinde' er for langst gået ud af sproget og erstattet af blot 'skuespiller'. Men er kønnet helt uvedkommende $i$ skuespillets verden? Danske kvindelige skuespilleve stair over for en rakke kønsrelaterede dilemmaer.

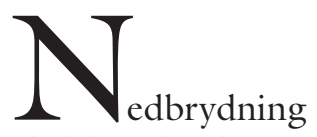

af den kønsmæssige arbejdsdeling har længe stået højt på den ligestillingspolitiske dagsorden i Danmark. Kønsarbejdsdelingen forstærker ulighed i forhold til løn, karrieremuligheder og adgang til udfordrende jobmuligheder, og den skaber og forstærker kønsstereotype forestillinger om, hvad henholdsvis kvinder og mænd er gode til (Holt 2006). Imidlertid overgår skuespillerfaget langt de fleste andre fag i kønsopsplitning. For kvindelige læger og jurister er uddannelsen adgangsbillet til det arbejdsmarked, som er for jurister og læger, uanset om man er kvinde eller mand. Men er man uddannet skuespiller og kvinde, så er det stadig kun den særligt kvindeligt konnoterede del af rollerne, som man får adgang til. Samtidig skal man med sin krop producere kvindelighedsudtryk, der dels er nedfældet i den foreskrevne rolle, dels tolkes af en given, oftest mandlig instruktør, og opleves som autentisk 'kvindeligt' for et ikke nærmere defineret publikum. 
I 2006-2007 gennemførte vi en undersøgelse for Kunstrådet (Kirkegaard \& Sjørup, 2007), der skulle tage temperaturen på ligestillingssituationen inden for alle fire kunstneriske retninger: Scenekunsten, musikken, billedkunsten og skønlitteraturen. Vi har gennemført i alt 23 kvalitative interviews med kvindelige kunstnere, heraf 6 med skuespillere, to med operasangere og to med kvindelige instruktører. Det er disse interviews, vi tager udgangspunkt $\mathrm{i}$ her. Vi har fokuseret på de sociale og ligestillingsmæssige vilkår for de kvindelige kunstnere samt de vilkår, under hvilke kvindelighed reproduceres. Vilkår der af skuespillerne opleves som begrænsninger $i$ at udtrykke eller konstruere deres egen 'kvindelighed' i kunsten. ${ }^{1}$

Alene det, at undersøgelsen blev igangsat, viser, at ligestillingsdiskursen er sat på dagsordenen i kunstverdenen. Diskussionen om de kvindelige kunstneres fravær i kulturkanonen var en af de anledninger, der bragte denne dagsorden frem (Møller Jensen 2007, Bissenbacker 2006). En anden var diskussionen om de kvindelige billedkunstneres sparsomme repræsentation på de danske kunstmuseer (Kulturarvstyrelsen 2005). Der har hidtil været mindre fokus på skuespilkunstens verden. ${ }^{2}$ I denne artikel vil vi derfor især fokusere på skuespillere inden for film, tv og teater. Det særlige ved skuespilkunsten er, at værket ikke træder ud af kunstnerens krop, sådan som det gør, når man maler et billede eller skriver en roman. I skuespilkunsten er værket i kroppen, fremhævet af makeup, kostume, frisure eller lyssæxtning. Værket udtrykkes i denne krops evne til at bære rollen autentisk, således at kroppen bliver ét med værket og ikke blot opleves som en given kunstner, der fremfører en rolle på en scene.

Til trods for at den aktuelle ligestillingsdiskurs også er tydeligt repræsenteret blandt skuespillerne, foregår opsplitningen af skuespilkunsten $\mathrm{i}$ et kvindeligt og et mandligt arbejdsmarked med den selvfølge- lighed (Funch Ellehave \& Søndergaard 2007) og umiddelbare accept og genkendelighed, som omgiver fremstillingen af køn som absolutte modpoler i det mandlige og det kvindelige. Skuespilkunst er først og fremmest en 'performance', det vil sige den enkelte kunstners evne til at fremstille et værk, en figur eller situation, så vi genkender det som kunst. I skuespillet foregår denne selvudfoldelse som regel i et kollektiv, hvori man skal kende sin rolle i relation til manuskriptet, og hvor instruktøren i samarbejde med scenografen, lys- og lyddesigner, kamerafører, teknikere m.fl. i større eller mindre grad afstikker rammerne inden for hvilke, den enkelte kan udfolde sin personlige kreative 'performance'.

Det betyder, at fremstillingen af kvinde$k ø n$, ud over skuespillerens egen ageren af sit køn inden for rammerne af foranderlige kønskoder, foregår i en kønnet krop, der udgør den situation, som danner baggrund for beskuerens genkendelse af skuespilleren som karakter og som køn. Samtidig er der lagt mindst to andre medskabende lag ind, manuskriptet og instruktøren, der i dialog med skuespilleren konstruerer et specifikt kønsudtryk inden for de afstukne skabeloner. Der er imidlertid i øjeblikket opbrud i de former, hvori kønnet er repræsenteret i moderne teater blandt andet gennem den store interesse, der i de seneste år er blevet knyttet til queer-begrebet og de mere udflydende fremstillinger af køn. Der var dog ingen af de interviewede skuespillere, der, da vi interviewede dem i efteråret $2006 \mathrm{og}$ foråret 2007, havde erfaringer med denne tendens.

\section{ARBEJDSMARKEDET FOR KVINDELIGE SKUESPILLERE}

Når man taler om skuespil som kunst, forekommer det måske ikke umiddelbart relevant at betragte det som et fag eller et arbejdsmarked. Ikke desto mindre findes der et par tusinder personer i Danmark, der opfatter skuespillet som deres levevej, og som 
forventer at kunne forsørge sig selv med faget, få tarifmæssig løn, arbejdsløshedsdagpenge og muligheder for barsel- eller sygedagpenge. Mens man for en generation eller to siden betragtede kvinder som primært forsørgede af familie eller en xgtemand, uanset om det var berettiget eller ej, så er vilkårene for danske kvinder i dag, at de skal kunne forsørge sig selv, og at de engagerer sig i uddannelse og faglige organisationer med henblik på at pleje deres arbejdskraft bedst muligt. Det gælder også kvindelige kunstnere. Blandt de skuespillere, vi interviewede i undersøgelsen, var der ingen, som levede i et parforhold, hvor de regnede med at blive forsørgede.

De kvindelige skuespillere gav udtryk for, at for kvindernes vedkommende er de fleste roller skrevet til de unge og smukke. De siger, at det betyder, at mange smukke og talentfulde kvinder kommer ind i skuespillerfaget som ganske unge uden nogen form for uddannelse. De har ungdommen, skønheden og talentet som væsentligste konkurrenceparametre og er derfor stærkt privilegerede af denne særlige menneskelige kapital. De har forudsætningerne for at spille rollen som den unge attråede kvinde, om hvem spillets romantiske intrige drejer sig, og dermed har de også hyppigt rollen som en hovedfigur i spillet.

Derimod findes der kun få kønsneutrale roller, som kunne spilles af medlemmer af det ene eller andet køn. Rollerne som magtfulde eller professionelle personer som regenten, ministeren, lægen eller juristen, som i virkelighedens verden i dag lige så hyppigt besættes af kvinder, bliver ifølge vore interviewpersoner i skuespillets manuskript eller i henhold til sædvanen med selvfølgelighed besat med mandlige skuespillere og dermed grundlæggende mandligt konnoteret. Vi har i vort interviewmateriale et eksempel på en kvindelig skuespiller, som var blevet tildelt rollen som borgmester i et teaterstykke. Da dette kom teaterchefen for øre, blev hun imidlertid taget af rollen, da man ikke efter dennes mening kunne fore- stille sig, at en kvinde var borgmester. Man kunne forvente, at denne stereotypisering ville blive opblødt som følge af udviklingen i det virkelige liv, men ud fra vore interviewpersoners udsagn kunne man næsten få et indtryk af det modsatte: Kønsstereotypiseringen genspilles snarere som et gentaget udsagn om eksistensen af nogle mere basale køn, hvor nutidens kvinder ses som en tilfældig og midlertidig undtagelse.

Ledighedstal fra Dansk Skuespillerforbund illustrerer forskellen på beskæftigelsen for kvindelige og mandlige skuespillere. Selv om der optages lige mange kvindelige og mandlige elever på de anerkendte skuespillerskoler, er der en tredjedel flere kvindelige end mandlige skuespillere organiseret i Skuespillerforbundet. Der er en ledighedsprocent på 27 pct. for mandlige skuespillere og 34 pct. for kvindelige (2006). Næsten dobbelt så mange kvinder som mænd forlader erhvervet, som oftest efter mange aktive år. Frafaldet sætter for alvor ind for kvinderne $\mathrm{i}$ aldersgruppen 40-49 år, hvor 22 pet. er ude af erhvervet mod 12 pct. af mændene.

\section{LøN}

Skuespillernes arbejde med teater, film, TV og reklame er meget stærkt markedsafhængigt. Der er kontant afregning for hver opgave, og indtjeningen afhænger af succesen i den enkelte opgave. Der er gode billeder i de kvindelige stjerner, som samtidig må kæmpe hårdt for at holde sig på toppen, især fordi der altid står nye og yngre talenter klar i kulissen. Tilsyneladende er de mandlige skuespillere mindre afhængige af denne markedslogik. De kan bedre holde en stabil beskæftigelse, og det gælder tilsvarende, at mandlige skuespillere er bedre aflønnede end kvindelige. En undersøgelse fra Skuespillerforbundet viser en stor lønspredning blandt skuespillere, men i alle løngrupper tjener de mandlige skuespillere væsentligt mere end de kvindelige (Krøll 2003). Skuespillerne i vores undersøgelse 
fortæller os samstemmende, at de kæmper med, at kvindelige skuespillere ikke kan opnå den samme løn som de mandlige, også når de har en hovedrolle på samme niveau som dem. Samtidig udviste de kvindelige skuespillere en stor bevidsthed om lønforskellene og en forurettethed om samme, som man måske ikke tidligere har set.

En anden særlig præmis, som fylder mere for kvindelige skuespillere end for deres mandlige kolleger, er den tid, som de skal investere i deres udseende eller rettere sagt i maskeringen. Kroppen er ikke blot det lærred, som rollen udspilles på: Det rå kvindelige lærred fremstiller sjældent den idealiserede kvindeskikkelse, som rollen fordrer.

\section{"Hvis man spiller en mindre rolle og fär en} mindre rolle på film, så har man også sin kalender fuld. Det er noget andet for drenge. Men pigerne, vi bruger den dobbelte tid. For der er altid noget med hairet, sminken eller tøjet. Pà en filmdag vil jeg typisk skulle mode $\mathrm{kl} .5 \mathrm{om}$ morgenen, og så kommer drengene kl. 7. Det er vigtigere, hvordan piger ser ud. Man skal prove fire stativer med toj, du kan stå $i$ en hel uge og hive op $i$ tojet for at prove. Det har slet ikke flyttet sig. Man bliver så misundelig på drengene. De fär mere $i$ lon og bruger den halve tid. Det er ikke vigtigt på samme måde, om de har sovet 8 timer eller ej." (Skuespiller i 30'erne)

Det betyder, at kvinderne har langt sværere ved at klare flere roller på én gang, eksempelvis at lave film om dagen og optræde på teateret om aftenen. At krybe ind i rollen kræver betydeligt mere tid for den kvindelige end den mandlige skuespiller, og samtidig lægges der stadig flere lag på af udsagn om det kvindelige, når kostumet, frisuren og makeup'en lægges til.

\section{AT BLIVE GRAVID OG FÅ BØRN}

De kvindelige skuespillere i undersøgelsen siger, at det kan være en katastrofe at blive gravid. Også selv om man er i 30'erne og dermed har passeret den alder, hvor de fleste jævnaldrende har fået børn. Alligevel er der et stærkt ønske om at få børn hos de kvindelige skuespillere $\mathrm{i}$ interviewmaterialet, der endnu ikke har fàet nogen. Når det kan være en katastrofe at blive gravid, så handler det for det første om, at de spor, som graviditet og fødsler sætter på kroppen, gør det vanskeligere at illudere ung og uberørt.

“Og hvis jeg skulle vare sà heldig at blive gravid, så kan jeg ikke arbejde. Jeg ville kunne lave radioteater eller undervise, men jeg ville skulle stoppe min karriere som primadonna. Det bliver svereve at komme tilbage efter børn." (Skuespiller i 30'erne)

For det andet arbejder skuespillere ofte på tidspunkter, hvor andre har fri, og hvor børnene ikke kan blive passet i daginstitution eller skole. Hverdagen med børnene kan være næsten umulig at få til at hænge sammen. En længerevarende turné slider også hårdt på familielivet og rollen som mor.

“Det er et enormt slid at skulle arbejde så meget, mens man er gravid og har smà born. Det koster ofte en skilsmisse. Det støder mand aldrig på. Det har også konsekvenser for mend, når de fär born, fordi de aldrig kan vore hjemme om aftenen og putte deres born, men der sker ikke noget med deves tilbud. Og det er ikke så meget anderledes end for så mange andre mand. Der er en anden pris for kvindelige skuespillere, $i$ hvert fald på det plan, som jeg er havnet $i$. Jeg har altid helt vildt gerne villet have born." (Skuespiller i 30'erne)

For de fleste skuespillere betyder det, at de ikke får nogen roller, når de er gravide eller planlægger at blive det. En fortæller dog, at hun spillede en ikke-gravid rolle frem til 7. måned og kun havde 4 måneders barsel, hvilket havde været ubærligt hårdt, særligt fordi hun skulle på turné og dermed rejse fra et meget lille barn. 
De interviewede kvinder har for det meste haft partnere eller familie til at passe børnene om aftenen, men ellers er der et gevaldigt pasningsproblem. For de fleste har det været fraværet om aftenen i lange spilleperioder, der har været det største problem. En af dem foreslår at være to om den samme rolle, når det er længerevarende produktioner, så hun kunne nøjes med at arbejde hver anden aften eller hver anden uge. Det er ikke en ukendt ordning blandt andet i operaen, hvor det kan være vanskeligt at synge store partier hver aften i en længere periode.

\section{ALDER:}

MORLILLE ELLER AMME, LUDER ELLER MADONNA

Der kommer mange helt unge talenter ind $\mathrm{i}$ branchen, men hvis en skuespiller går den slagne vej og søger ind på skuespillerskolerne efter studentereksamen, og måske ikke er helt klar og derfor tager timer privat, vil hun typisk være 25-30 år, før hun er færdig. Hvis hun gerne vil have børn i 30-35 års alderen, hvor de fleste nu får børn, så har hun kun fem år til at opbygge sin karriere. Skuespillerne i undersøgelsen taler samstemmende om 40-års alderen som et særligt problem for kvindelige skuespillere. Fra da af er der ikke mange roller tilbage, hverken i de klassiske stykker eller i de nye produktioner. Der er få undtagelser fra dette mønster blandt andet Ghita Nørby, som er det store forbillede, fordi hun har kunnet følge sine aldre og få gode roller $\mathrm{i}$ alle aldrene. Men for langt de fleste er der kun hustruen og ammen i hjørnet tilbage.

"De mandlige skuespillere har mange flere roller at velge imellem, og mange forudsetter heller ikke, at man er ung, mens der er ferre roller til kvinder over 40, som hyppigt ender $i$ rollen som morlille eller amme. Indtil da luder eller madonna. Kvinder over den alder er ikke interessante. Og de fleste ender uden nogen jobs overhovedet." (Skuespiller i 60'erne)
Nogle af skuespillerne begrunder dette, at de kvindelige skuespillere og operasangere helst skal være så unge og dugfriske som muligt, med det simple, at rollerne i de klassiske rollefag er skrevet til helt unge kvinder, omkring hvem den erotiske intrige drejer sig. Andre begrunder det med instruktørernes subjektive behov for at spejle sig i ungdommen, og at Pygmalion-temaet, hvor den xldre og erfarne mandlige lærer oplærer den unge og uvidende kvindelige elev, både spilles og genspejles i forholdet mellem instruktør og skuespiller, dirigent og sopran.

“Aldre instruktorer også på Det Kongelige var forelskede $i$ den der ungdommelige kvindetype, der er ren, indtil de kan forme hende, den der Pygmalion-ting. Og der er ikke noget bedre end, at man kan se sig genspejlet i noget, der er smukt og ungt og yndigt. Det er en stor fristelse for dem, sà er det op til den unge pige, om bun vil spille med på de der følelser, eller om hun kan sige, leger vi ikke godt nu. Jeg ved godt, hvor du vil hen, det er sødt af dig, men jeg skal hjem nu." (Operasanger i 30'erne)

En operasanger i undersøgelsen peger på, at de klassiske operaroller i sig selv er skrevet til væsentligt yngre kvinder end dem, som nu synger dem. Hun siger, at illusionen brister med den nye teknologi, der bringer close-up billeder, og gør det sværere for de ældre kvinder at illudere i rollen som den unge uskyldighed, samtidig med at det kræver stemme og erfaring at synge de store partier. Til gengæld kan de lidt $æ l-$ dre sangere lægge en distance eller en ironi ind i rollen, der gør, at de i realiteten kommer til at fremstå som den xldre vidende kvinde i stykket:

"Mange operaer er jo skrevet til unge piger. Tosca er vel en pige pà 17, og de andre Puccinikvinderoller er jo skrevet til unge kvinder. Og det hele er blevet så visuelt. Man ser jo mange close-ups, det så man ikke i gamle dage, da kunne man jo let bruge nogle tricks, nu kan 
man jo se alle panderynkerne. Jeg illuderer jo den unge skønne kvinde, det vil sige, det gør jeg jo ikke så meget mere, men nu spiller jeg jo den eldre vidende kvinde, og det kan pigerne blandt publikum godt lide, og min mandlige modspiller bliver jo spiddet lidt. Han kan ikke altid lide det, for han foler sig udstillet."

(Operasanger i 50’erne)

Den mindre efterspørgsel på kvindelige skuespillere over 40 år kan også have andre konsekvenser for kvinderne, nemlig at de er nødt til at få foretaget kosmetiske operationer for stadig at være med i kampen om rollerne. Dette fænomen er allerede stærkt udbredt i USA, og med den forbedrede optageteknik og billedkvalitet vil dette krav vokse de kommende år. De danske skuespillere i undersøgelsen havde da også måttet tage stilling til spørgsmålet, om hvorvidt man skulle underlægge sig kniven for at bevare det rette unge udseende. Dette gælder særlig TV- og filmproduktion, men også i operaen.

Det at blive oplevet som autentisk, at passe til rollen, betyder altså i dag for de kvindelige skuespillere, at de må kunne fremstille en kropslig uberørthed. Samtidig er rolleudbuddet begrænset af kravet om ungdom, et krav, som yderligere understreges af instruktørernes og teaterchefernes billeder af det idealiserede kvindelige.

\section{AT LEGE MED KØNNET:}

\section{OPRØR OG KRAV OM LIGESTILLING}

De fleste af de interviewede skuespillere var uhyre bevidste om ligestillingsdilemmaerne i deres arbejde og havde stort set alle været vrede over de begrænsninger, som de bliver underlagt. En skuespiller i 40'erne efterlyser en større frihed i forhold til kønnet og de traditionelle kvinderoller.

\section{"Jeg har faktisk provet at spille manderoller,} bvor jeg skulle spille mand. En gang var det en tvekønnet, som 'gik' som mand, men som godt kunne bytte over og pludselig blive meget kvin- delig. Og jeg har spillet saidan en rigtig mandemand. Og det var skide sjovt, fordi kropssproget skal virkelig endres. Og jeg har spillet en femme fatale, der brugte bàde sine feminine og maskuline sider utrolig meget. Og der er så meget POWER $i$ det. Nar jeg har haft de der rolleraltså der er bare så meget POWER $i$ at få lov til at give luft for sine mandlige sider, nàr man er kvinde. Det er helt vildt. Og hvad er det? Hvad er det vi gàr og undertrykker? Fordi den power har jeg jo så åbenbart." (Skuespiller i begyndelsen af 40 'erne)

De erfaringer, som hun har haft med at slippe det, som hun med et jungiansk begrebssprog betragter som sine maskuline sider, løs, fortæller hende, at hun tilbageholder meget af sin egen kraft til daglig og i kunsten. Denne kraft slippes åbenbart kun ud i den frihed, der opstår, når også hendes maskuline sider leves ud. Samtidig er det hendes erfaring, at nogle mænd har nøjagtig samme behov for at slippe deres feminine sider ud. Men hendes oplevelse i det daglige arbejde er, at kvinder bliver fastholdt i højst fem forskellige arketyper af kvinderoller, hvilket hæmmer de kvindelige skuespilleres muligheder for at udfolde deres talenter.

"Det er mit mål $i$ det lange lob at få lov at lave noget mere kantet. Noget mere af den der dobbeltsidighed, som vi bestàr af. Jeg tror, at vi alle indeholder forskellige mongder af baide noget mandligt og noget kvindeligt." (Skuespiller i 40'erne)

Flere mener, at det er kedeligt altid at skulle spille kvinderoller, som er defineret af traditionen og handler om kvinders særlige problemer, eller som er defineret af mænds opfattelser af kvinder. En skuespiller i 40 'erne oplevede at komme fra provinsen til København i 90'erne og få et chok over, at det hele fungerede gammeldags på et moderne teater. Teateret var ifølge hende direkte mandschauvinistisk og ekstremt topstyret. Kvinderollerne bestod udeluk- 
kende af ludere eller madonnaer - og madonnaen var også lidt luderagtig. Dette står i modsætning til mænds roller, som der dels er mange flere af, og som dels får lov til at dække et langt større spektrum af persontyper og adfærd. Manderollerne handler i hendes erfaring sjældent om at være mand men om at være menneske.

Flere af skuespillerne efterlyser roller og historier, der handler om kvinder som mennesker og ikke kun fokuserer på kvinder som en særlig art med særlige problemer. Samtidig oplever flere af dem, at det er med til at fastlåse kvinder, at de reduceres til at være enten madonna, luder, moder, amme eller hende, der bliver forladt.

\section{Magtspillet, KØNSSPILLET OG SKUESPILLET}

Det er en klar overvægt af mænd, der styrer i kulisserne, både når man ser på teaterdirektører, manuskriptforfattere og instruktører, selv om vi efterhånden ser en ny generation af kvindelige instruktører og teaterledere, der markerer sig med stor succes. Men det kan være svært som kvindelig instruktør at rejse penge til de produktioner, man brænder for. En kvindelig instruktør fortæller, at det forventes, at kvinder udelukkende laver 'tøsefilm', og at det vil være umuligt for en kvindelig instruktør at få lov at lave action- eller gyserfilm.

Da det desuden ofte er mænd, der besætter rollerne, oplever nogle af kvinderne, at de kæmper på ulige fod med mændene. De tager måske knap så professionelle metoder i brug.

“Der er stadig fem gange så mange manderoller som kvinderoller, og kvinderne skal gore sig meget til for at klare sig. Og skal kampe umadeligt meget for at komme til. Og jeg tror da ogsà, der er mange, der velger at gøre det $p a ̊$ den 'kvindelige facon', om man sà mà sige. Altså ved at vere meget behagelige, kvindelige, sørge for at se beundrende pa mend med magt - det lever stadig $i$ bedste velgående. Og det nytter noget. Det kraver selvfolgelig stadig, at du er dygtig til dit fag, men det er der jo rigtig mange, der er. Så man skal vere fem gange dygtigere end mondene for at klare sig. Og sødere og panere." (Skuespiller i 40'erne)

De økonomiske midler inden for scenekunsten bliver primært fordelt af mænd, der åbenbart 'giver dem videre' til andre mænd. Flere kvinder kritiserer mændene for manglende professionalisme, når så få kvinder făr lov at folde sig ud og få del i midlerne og magten:

\section{"Det Kongelige bruger sjeldent en kvindelig} dramatiker. Det er ren topstyring. Store egoer der kommer til magten, og de giver den videre til andre hvide mand på 30 til 50 àr. 80 pct. af midlerne til scenekunsten i Danmark bliver fordelt af mand. Og når man påpeger det, så far man at vide: Ja, ja, ja-men den kunstneriske fribed. Den spenske rapport påviser, at det kun er en meget lille gruppe, som har kunstnerisk fribed, og så er der ikke kunstnerisk fribed. Det andet begreb er kvalitet. Hvem bestemmer, hvad kunstnerisk kvalitet er, nàr det er den samme lille gruppe af mand, som fär kunststotte. Det er ikke professionalitet, som er kriteriet." (Instruktør og skuespiller i 40'erne)

Interviewpersonen refererer til den svenske rapport Plats på Scen (Kulturdepartementet 2006), som er en omfattende ligestillingsplan for den svenske teaterverden. Der skal i ledelserne fremover være mindst 40 procent kvinder. Der har ikke været tilsvarende initiativer i Danmark, selv om gruppen Agenda 009 gennemførte et delvis succesfuldt lobbyarbejde for at få flere kvinder i teaterledelserne, da disse blev nybesat i 2006.

En instruktør fra den alternative scene oplever, at hele diskussionen omkring køn og diskrimination er forbundet med de store institutioner. Det har også den konsekvens, at hendes teaterforestillinger kan fejre store succeser i udlandet og få priser for at være eksperimenterende og nytænkende, 
samtidig med at det er helt umuligt at få dem opført på de store teatre i Danmark. Oftest får hun ikke engang et svar, når hun skriver og spørger.

En instruktør og skuespiller fortæller, at hun foreslog et stykke til en teaterdirektør og slet ikke kunne komme igennem med sit budskab. Teaterdirektøren blev ved med at småflirte med hende i telefonen, og hørte slet ikke hendes budskab om at ville sxtte et stykke op på 'hans' teater, selv om hun insisterende blev ved. Først da hendes mandlige kollega ringede op, skete der noget. Teaterdirektøren var lydhør med det samme, og forestillingen blev sat op. Der lyttes åbenbart til kvinder og mænd med meget forskellige ører og/eller forventninger.

En anden instruktør fortæller, at hun som regel ikke har et problem med at instruere mænd. Det er først, når der opstår problemer, og hun bliver ved med at kræve noget bestemt, at de mandlige skuespillere stiller sig på bagbenene. De bliver provokerede over, at hun fastholder krav over for dem. Hun mener, at de helst vil have, at hun bliver i rollen som 'den søde mor'. En skuespiller fortæller, at det ofte er nødvendigt eller velset, at kvindelige skuespillere ikke sætter for mange spørgsmålstegn ved mandlige instruktørers metoder og fortolkninger.

"Man skal heller ikke vere alt for intellektuel. Serligt hvis man arbejder med mandlige instruktorer, så kan de godt lide lige at vere den tak over én. Og jeg har klart en fornemmelse af, at det ikke er lige så stort et problem, bvis de mandlige skuespillere kan finde ud af at lese boger og tenke selv. Det er helt klart noget, jeg har oplevet, og jeg bliver sà glad, hvis jeg oplever, at det ikke er sådan." (Skuespiller i 40'erne)

Selv om der er nybrud i magtrelationerne mellem kvinder og mænd i film og teater, så er det markant og chokerende, at de danske kvindelige skuespillere og andre scenekunstnere, som vi har talt med, oplever så massiv en mandsdominans i de ledende lag. De hyppigt meget erfarne og veluddannede kvindelige skuespillere, som ønsker at sætte deres præg på produktionerne, giver udtryk for, at det næsten er umuligt at trænge igennem. Selv om de faktisk har gennemført vellykkede produktioner, bliver de hyppigt ikke bedt ind igen.

\section{TiltræKNING ELLER OVERGREB}

I skuespilkunsten, der er så fysisk og kropslig i sin form, er det åbenbart svært at finde grænserne for, hvad der er tilladeligt, og hvad der er grænseoverskridende. En lang række af de kvindelige skuespillere har haft oplevelser, som de har opfattet som krænkende. På grund af den ofte ulige magtfordeling kan det være svært at sige fra. For skuespillere kan det være instruktøren, der udnytter sin stilling. En skuespiller fortæller, at det engang blev så slemt, at hun forsøgte at komme ud af rollen. Hun blev mødt af mistro fra en anden mandlig overordnet, der åbenbart mente, at hun nok selv var ude om det.

\section{"Ja, det er startet med det samme og er en} enormt sver ting at tackle. Det er enormt hàrdt. Tit i forbindelse med samarbejde. Ikke nair jeg har skullet have en rolle. Men med instruktoren, som sidder og ser på en og ikke ser mig, men det han ønskede at se. Der var engang en, som ringede til mig hele tiden og gik fra sin kone. Og det blev så voldsomt, han begyndte at terrorisere mig og ville have mig til at prøve hele tiden alene. Jeg bad chefen om at komme ud afforestillingen. Han sagde, er du ikke selv ude om det. Men sàdan er det jo at vere kvinde $i$ verden. Du kan ikke regne med at finde forståelse, du kan vore heldig at finde den. Jeg har lert at se det og gå uden om det." (Skuespiller i 30'erne)

Det behøver ikke nødvendigvis at være en decideret afvisning af konkrete seksuelle tilnærmelser fra den mandlige overordnede nogle gange kan manglende seksuel interes- 
se være nok til, at kvinden udsættes for straf gennem det resterende arbejdsforløb.

En operasanger fortxller, at hun oplever en gensidig erotisk tiltrækning med en instruktør, når de arbejder med at sætte et stykke op, men at det blot er en 'del af legen' for at få det hele til at hænge godt sammen. Følelsen forsvinder ved premieren.

"Men jeg har ikke voret med på den galej, men jeg vil sige det på den måde, at jeg meget, meget tidligt fandt ud af, at du kan vore i en forestilling med en instruktor, som du virkelig arbejder veldig godt sammen med, saidan pingpong, og det nermer sig et erotisk forhold, fordi du tror faktisk, at du er forelsket $i$ vedkommende. Men lige så snart premieren er overstået, så er folelsen vek. Og har du det $i$ dit baghoved, at det her er ikke noget, som er virkeligt, så kommer $d u$ ikke ud $i$ det ufore, at du kommer til at ligge med en person eller forelske dig $i$ et menneske, som rent faktisk er på arbejde." (Operasanger i 40 'erne)

Den tætte fysiske kontakt, der er i arbejdet, og det entydige afhængighedsforhold gør den kvindelige skuespiller eller operasanger til et hyppigt offer for uønsket seksuel opmærksomhed. Det sker sikkert også, fordi det kan være fristende for den unge og uerfarne skuespiller at udnytte denne 'erotiske magt' til at tiltrække sig mere opmærksomhed og nye roller.

\section{AT PERFORME KØN}

Som nogle af vore interviewpersoner udtrykker det, opererer de i deres kunst ikke med en essentiel forestilling om køn, men tværtimod er de ofte i konflikt med de mandlige instruktører og teaterledere om tolkningen og fremstillingen af køn i produktionerne. En af billedkunstnerne i vores undersøgelse fortæller specifikt, hvordan hun selv arbejder med inspiration fra Judith Butlers teorier om køn som konstruktion og performativitet, altså køn som skabes og genskabes i de konkrete handlinger og det konkrete, levede liv. Men hun siger, at når hendes værker anmeldes, udsættes de ofte for en ureflekteret kønsessentiel tolkning, der reducerer det kvindelige til krop og seksualitet.

Både denne kunstner og en rakke af de øvrige udtrykker det, man i kønsforskningen ville betragte som 'queer-perspektivet' (Butler 1993), nemlig at de afsøger eller forsøger at udfordre dikotome forestillinger om køn. Enkelte af interviewpersonerne udtrykker en særlig kunstnerisk kvalitet i at udforske grænserne mellem 'maskuline' og 'feminine' sider af sig selv, og den måde de dermed udfolder deres rolle i kunsten. De fortæller, hvordan de forsøger at udfordre de stærkt heteronormative kvinderoller særligt i det klassiske rollefag, eller måske snarere de roller, der særligt knytter sig til den tidlige modernismes mandlige kunstneriske udtryk. Hvor kvindelige billedkunstnere og litterater kan udfordre kvindestereotyper $\mathrm{i}$ fremstillingen af den kvindelige krop og erfaringsverden, er skuespilleren eller operasangeren i langt højere grad fanget ind af kønsstereotyperne $\mathrm{i}$ de klassiske roller. Hun kan udfordre dem med en vis distance eller ironi, men de begrænser hende alligevel til en figur, som i de fleste tilfælde er skabt af en mandlig dramatiker som omdrejningspunkt for en mandlig livsudfoldelse eller et mandligt begær. Oven i købet skal den kvindelige skuespiller eller operasanger i de nye medier i langt højere grad være autentisk i rollen, og dermed skabes også en dyrkelse af de unge, rene og uskyldige udtryk, som er så flygtige og eftertragtede. Den kvindelige skuespiller eller operasanger kan næsten ikke nå at gennemføre uddannelsen, før denne særlige magi er forsvundet.

De kvindelige kunstnere er således i meget høj grad præget af den dobbelthed, som er i kvindebilledet i dag: På den ene side fejringen af den kompetente, veluddannede og ligestillede professionelle kvinde og på den anden side fejringen af kvinder 
som begxrsobjekt, af ungdom og seksuel udstråling og uberørthed. På den ene side den kvindelige kunstners udfordring af et dikotomiseret kønsbillede og på den anden side den rolle, hun forventes at spille som en 'rigtig' kvinde. Det er jo unægteligt et dilemma, som selv den unge kvindelige skuespiller, der netop fejres for sin purunge uskyldsrene udstråling, udtrykker så klartseende og brutalt, når hun fortæller om de mange ubetalte timer, hun må tilbringe $\mathrm{i}$ sminkørens, frisørens og kostumierens hænder for at kunne udtrykke denne uberørte kvindelighed, mens den bedre betalte mandlige hovedrolleindehaver kommer blæsende i sidste øjeblik og straks kan udtrykke den rette rå og nøgne maskulinitet.

\section{KonKLUSION}

De kvindelige skuespillere føler sig ofte fanget $\mathrm{i}$ en række konfliktfyldte dilemmaer i konstruktionen af køn, som afspejler de dilemmaer, der ligger i tiden i sammenstødene mellem en ligestillingsdiskurs, som de selv er en virksom del af, og de roller, de tilbydes især i det klassiske rollefag, hvor kvindelighed især udspiller sig som den attråede romantiske unge kvinde. Det betyder, at skuespillet på én gang er et fag og en professionalitet, der er forsørgelsesgrundlag for kvinder og samtidig også reproducerer et traditionelt kvindebillede, hvor kvinder reduceres til deres seksualitet.

Der eksisterer også et dilemma mellem en mandlig magtelites implicitte forestillinger om idealiseret kvindelighed, på den ene side (dog modificeret af nye tendenser, blandt andet aktuelt på Betty Nansen teateret, Camp X og Nørrebros teater, til at se kvinder på en anden og mere nuanceret måde), og på den anden side den enkelte skuespillers professionelle udfordring $i$ at lege med kønsudtryk og det mandlige og det kvindelige og dermed søge at undgå at blive reduceret til et spejl på den kvindelige seksualitet.

Yderligere er dilemmaet modsætningen mellem på den ene side kroppen som situation (Moi 1999, Munk Rösing 2005), som en absolut virkelighed, der sætter fokus på den kropslige ældning, og gør det på forskellig vis for kvinder og mænd, og på den anden side kravet om respekt for en professionalitet, der eksisterer uden tilsvarende absolutte kropslige bindinger.

Endelig er der dilemmaet mellem at skulle producere drømme i en stadig mere markedsklemt oplevelsesindustri, hvor kvindelig seksualitet, ungdom, skønhed og diametrale forskel fra mænd dyrkes, samtidig med at man lever i en tid med forestillingen om, at sådanne kønsspecifikke barrierer for længst er nedbrudt.

Som udefra udspørgende kønsforskere var vi overraskede over at møde en så udtalt ligestillingsdiskurs blandt de kunstnere, vi interviewede. Vi har overvejet om kunstnernes, måske særligt skuespillernes evne til at mime, at tage imod instruktion, også kunne påvirke deres svar til os i en retning, hvor de forsøger at imødekomme det, som forventes at være vores intention, nemlig at finde kønsulighed blandt kunstnere. Samtidig ville det være et overgreb på vore interviewpersoner, hvis vi lod en sådan refleksion påvirke vores tolkning af deres udsagn. Det forekommer imidlertid berettiget at spørge, om der faktisk sker en stærkere fastholdelse af kønsstereotyperne snarere end en opblødning, således som den udtalte queer-tendens ellers kunne antyde. Den heteroseksuelle kærlighedsintrige er tilsyneladende stadig godt stof i dramatikken og dermed også tendensen til at fastholde de to køn i nogle begærsstrukturer, der normaliserer det heteroseksuelle begær og fastholder kvinder i rollen som begærsobjekt eller offer for fravær af begær. 


\section{NOTER}

1. Det overordnede kriterium for udvælgelse af interviewpersoner var, at de skulle have to eller flere større værker eller opførelser bag sig og være anerkendt i offentligheden som kunstnere. De konkrete personer er dels fundet ved annoncering i relevante faglige medier og dels gennem brancheorganisationer. Der er tilstræbt en aldersmæssig spredning samt en forskel på, hvor kvinderne befinder sig i deres kunstneriske karriere, således at undersøgelsen rummer både de unge, der lige er kommet frem, og de xldre og mere erfarne kunstnere. Samtlige kunstnere er beskyttet med anonymitet i rapporten. De er derfor heller ikke angivet med navn i citaterne i denne artikel.

2. Vi har i undersøgelsen brugt begrebet scenekunst som samlebetegnelse for skuespil på teater, film og TV, fordi man i Kunstrådet anvender denne betegnelse.

\section{LITTERATUR}

- Bissenbacker Frederiksen, Maja (2006): Ikke et kulturelt kriseråb - Inklusioner og eksklusioner i debatten om den litterære kanon, i Kvinder, Køn og Forskning l/2006.

- Butler, Judith (1993): Bodies that Matter - On

the Discursive Limits of Sex. Routledge, New

York/London.

- Funch Ellehave, Camillla \& Søndergaard, Dorte Marie (2007): VIFA-projektet. 2. delrapport. Køn i den finansielle sektor. Kvinder $i$ ledelse $i$ finanssektoren. Danmarks Pædagogiske Institut, København.

- Kirkegaard, Charlotte \& Sjørup, Karen (2007):

Kvinder $i$ Kunst. Kunstrådet, København.

- Krøll, Christina (2003): Danske skuespillere i et erhvervsøkonomisk perspektiv. Skuespillerforbundet, København.

- Kulturarvstyrelsen (2005): Syv museers indkøbsmønster $i$ perioden 1983-2003. København.

- Moi, Toril (1999): What is a Woman? Oxford University Press, Oxford.

- Munk Rösing, Lillian (2005): Kønnets katekismus. Roskilde Universitetsforlag, Roskilde. - Møller Jensen, Elisabeth (2007): Kunst og køn kvinders bidrag til kulturen er blevet usynliggjort.
Politiken. 22/4/2007. Lokaliseret 7/2/2008 på http://politiken.dk/debat/kroniker/article289215.ece.

- Kulturdepartementet (2006): Plats på Scen. Statens Offentliga Udredningar 06:42, Stockholm.

\section{SUMMARY}

The article is based on a survey concerning gender equality among artists in Denmark, conducted in 2007. It particularly focuses on the situation of actresses as modern, well-educated and gender equality conscious women, placed in a dilemma between their own desire to deconstruct and reconstruct images of gender in their work and the traditional, gender-stereotypical roles offered to them. They moreover are the victims of late working hours and low salaries, making it very difficult to maintain themselves financially and to live a life as independent working mothers. Ageing is also a very difficult bodily experience for the actresses, who will often be excluded and replaced by younger actresses. There is however a battle going on between the gender equality oriented actresses and the primarily male directors and instructors, in charge of allowing modernisation of gender roles in films and theatre. In sum, the article explores how gender is constructed culturally and how femininity might be reformulated to challenge heteronormative gender stereotypes.

Karen Sjørup, sociolog, lektor ved Institut for samfund og globalisering, RUC. Tidligere leder af CeLi, Center for Ligestillingsforskning og direktør for Videnscenter for Ligestilling.

Charlotte Kirkegaard. konsulent, cand.jur., Unisex Progress. Tidligere forskningsassistent, Center for Ligestillingsforskning. 